\title{
A note on the bird diversity at two sites in Khartoum, Sudan
}

\author{
Osman Salah and Eihab Idris* \\ Department of Zoology, Faculty of Science, University of Khartoum. P.O. Box 321, \\ Postal Code 11115, Khartoum, Sudan \\ *E-mail: eihabidriss@gmail.com
}

\section{ABSTRACT}

The diversity of bird species is expected to vary with habitat type even at the smallest spatial scales. In this paper, we describe a preliminary survey conducted for the avifauna at two locations in Khartoum city, namely, Sunut forest and Tuti Island. The ecology of both sites is influenced by their proximity to the Nile River and thus they are characterized by dense vegetation cover. Moreover, the two sites lie very close to each other, implying that the climatic conditions are virtually identical. However, the two sites differ with respect to one major environmental respect, that is, the intensity of human influence. Tuti Island represents a man-made habitat and the vegetation at the site is mainly agricultural. On the other side, Sunut forest is a natural habitat and the vegetation cover at the site is dominated by the wild Acacia nilotica trees. The goal of the study is to compare the bird composition between the two sites in order to assess the effect of habitat type on the spatial variation in the abundance and diversity of birds. Overall, forty one species were recorded at the two sites during a five-month period: twenty four species at Sunut forest and thirty species at Tuti Island. Statistical investigation of avian diversity using Shannon index has detected a significant difference between the two sites, most likely due to variable human impact.

Keywords: Urban avifauna, biodiversity, spatial variation, Sunut forest, Tuti Island, Shannon index.

\section{INTRODUCTION}

Urbanization has substantial and multiple influences on biological communities. Among vertebrates, these influences have been most thoroughly investigated in birds as they are extremely abundant and easily observable group. The avian community composition was found to change considerably within city limits (e.g. Emlen, 1974; Askins et al., 1990; Bock et al., 2001). Urbanization favours special life styles among birds; the omnivorous, granivorous, and cavity nesting species were found to be more represented within urbanization spots than at the surrounding regions that belong to the same habitat. Exotic species are also favoured by urbanization (e.g. house sparrow and European starling). Likewise, fragmentation of natural forests through agricultural activities and suburban development significantly affects the bird communities, as is documented by several studies. As a general trend, increased urbanization leads to an increase in avian biomass but a reduction in species richness. The major factor that underlies the urbanization effect on avifauna is the vegetation cover. Birds respond to both vegetation density and composition. Supporting this, urban areas that retain native vegetative characteristics retain more native species than those that do not (Scott Mills et al., 1989; Marzluff, 1997). 
Al-Sunut is a natural forest which borders the White Nile at the Mogran area, Khartoum (Figure 1). Sunut forest is a unique biotope; a poor savannah habitat impeded in the semi desert background of Northern Sudan (Shawki \& Musnad, 1964).

As a consequence, the forest is characterized by high density of plant cover, mainly composed of Acacia nilotica trees (Mohamed, 1986; Ahmed, 1998). Moreover, it represents a hot spot of bird and invertebrate diversity; it has been estimated that the forest contains at least 70 bird species (among which 26 are migrants) together with a diverse invertebrate community (Cloudsely-Thompson, 1964; Nikolaus, 1987; Elobeid, 1990; Lado, 1994; Abd-Alrahman, 1998). The major environmental factor which underlies the unusual biodiversity at Sunut forest is the annual floods of the Nile River, which supplies the site with immense amounts of water and nutrient-reach sediments. Thus, the Sunut forest is considered as an inland wetland ecosystem (Altayeb \& Hamed, 2003).

Tuti Island lies at the union of the Blue Nile with the White Nile, where they form the main River Nile (Figure 2). It is surrounded by three towns: Khartoum, Omdurman, and Khartoum north (Bahri). Omdurman city lies on the western bank of the island; Bahri on the Eastern side, While Khartoum faces the southern bank of the island. Tuti is the home of one small village founded in the late 15th century, with grassland being the main makeup of the island. In the past, the only approach to Tuti Island was via several ferries that cross the river regularly, but now the Tuti Bridge, a modern suspension bridge, has been completed and it is used instead. Tuti Island contains large agricultural areas all around it and is considered as a major source of fruits and vegetables for Khartoum's population. The annual flooding of the Nile frequently submerges the south-eastern part of the island (Salah Eldin, 1997).

In this study, a preliminary survey has been conducted for the avifauna at Sunut Forest and Tuti Island during the period of Octoper-March 2011-2012. The avian diversity at the two sites was compared statistically. The differences in bird species composition between agricultural and wild habitats were discussed in the light of the field data obtained at the two sites.

\section{MATERIAL AND METHODS}

\section{Study sites}

This study was carried out at two locations in Khartoum city: Sunut forest $\left(15^{\circ} 35^{\prime} \mathrm{N}, 32^{\circ} 30^{\prime} \mathrm{E}\right)$ (Fig. 1) and Tuti Island $\left(15^{\circ} 37^{\prime} \mathrm{N}, 32^{\circ} 31^{\prime} \mathrm{E}\right)$ (Fig. 2).

\section{Climate}

The climate of Khartoum is tropical desert. There are three seasons per year, cool winter, dry summer and a rainy season. Highest temperatures $\left(45^{\circ} \mathrm{C}\right.$ or more) are recorded in summer months (May-June) while lowest temperatures $\left(22^{\circ} \mathrm{C}\right.$ or less) are recorded during winter months (December-January). The average rainfall is about 150 mm per annum. Nile flooding takes place during the rainy season (July-October) and affects both sites.

\section{Investigation of bird diversity}

The survey was conducted between Octoper 2011 to March 2012. Assessment of avifauna was based on bird observation. General observations were carried out by using a binocular $(7 \times 50)$ at least once a week for two study sites. Observations were carried out in different areas within the two studied sites. Species were identified by sight, using the field identification guide by Sinclair and Ryan (2003). Photographs of birds were taken by digital camera (Sony, 14.1 Mega pixels) whenever possible.

\section{Statistical analysis}


The species richness $(\mathrm{R})$ was determined as the total number of bird species at each site. The Shannon diversity index was applied to compare the avian diversity $\left(\mathrm{H}^{\prime}\right)$ and species evenness (E) between the two sites. Species diversity was estimated according to the following equation:

$H^{\xi}=-\sum_{i=1}^{R} p_{i} \ln p_{i}$

Where:

$p_{i}=$ relative abundance of species " $i$ ".

$R=$ total number of species.

$H^{\prime}=$ the Shannon Diversity Index.

Species evenness (equality) was calculated according the following formula:

$\mathbf{E}=H^{\prime} / H_{\max }=H^{\prime} / \ln R$

Where:

$\mathrm{E}=$ species evenness.

$H^{\prime}=$ the Shannon Diversity Index.

$H_{\max }=$ the value of $H^{\prime}$ if individuals in the community were completely evenly distributed.

$R=$ total number of species.

\section{RESULTS}

\section{Temporal changes}

The variations in the species composition that were observed between different months were shown in the Tables $(1 \& 2)$. Both Sunut forest and Tuti Island have experienced considerable significant temporal variations in bird diversity and abundance. A comparison of the total abundance of individuals between Sunut forest and Tuti Island during the five months of study was presented in Table (3).

Table 1: Temporal variation in bird species composition at Sunut forest during the period of OctoberMarch, 2011-2012.

\begin{tabular}{|c|c|c|c|c|c|c|c|}
\hline Common name & Scientific name & OCT. & NOV. & DEC. & FEB. & MAR. & Total \\
\hline Grey Heron & Ardea cinerea & 3 & 1 & 2 & 1 & 16 & 23 \\
\hline Black-Headed Heron & Ardea melanocephala & 1 & 2 & 52 & 15 & 9 & 79 \\
\hline Little Egret & Egretta garzetta & 23 & 28 & 33 & 62 & 90 & 236 \\
\hline Cattle Egret & Bubulcus ibis & 25 & 24 & 70 & 20 & 29 & 168 \\
\hline Greater Flamingo & Phoenicopterus roseus & 75 & 119 & 40 & 25 & 16 & 275 \\
\hline Pink-backed Pelican & Pelecanus rufescens & 6 & 3 & 2 & 4 & 8 & 23 \\
\hline White-faced Duck & Dendrocygna viduata & 0 & 0 & 2 & 2 & 2 & 6 \\
\hline Garganey & Anas querquedula & 0 & 0 & 3 & 2 & 2 & 7 \\
\hline Black Kite & Milvus migrans & 4 & 4 & 2 & 2 & 0 & 12 \\
\hline Senegal Thick-knee & Burhinus senegalensis & 0 & 7 & 5 & 4 & 2 & 18 \\
\hline Little Ringed Plover & Charadrius dubius & 13 & 14 & 8 & 2 & 1 & 38 \\
\hline Spur-winged Plover & Vanellus spinosus & 19 & 15 & 9 & 4 & 0 & 47 \\
\hline Common Snipe & Gallinago gallinago & 0 & 1 & 2 & 2 & 1 & 6 \\
\hline Black-winged Stilt & Himantopus himantopus & 4 & 2 & 2 & 2 & 0 & 10 \\
\hline Black-tailed Godwit & Limosa limosa & 6 & 5 & 4 & 5 & 7 & 27 \\
\hline Bar-Tailed Godwit & Limosa lapponica & 10 & 6 & 2 & 1 & 1 & 20 \\
\hline Dunlin & Calidris alpine & 6 & 6 & 2 & 2 & 0 & 16 \\
\hline Common Greenshank & Tringa nebularia & 0 & 0 & 6 & 4 & 3 & 13 \\
\hline White-winged Tern & Chlidonias leucopterus & 9 & 5 & 1 & 1 & 0 & 16 \\
\hline Pied Kingfisher & Ceryle rudis & 6 & 1 & 1 & 1 & 1 & 10 \\
\hline Crested Lark & Galerida cristata & 44 & 15 & 13 & 5 & 1 & 78 \\
\hline White Wagtail & Motacilla alba & 1 & 2 & 2 & 2 & 1 & 8 \\
\hline Yellow Wagtail & Motacilla flava & 4 & 5 & 3 & 4 & 4 & 20 \\
\hline House Sparrow & Passer domesticus & 25 & 18 & 15 & 9 & 8 & 75 \\
\hline Total & & 282 & 283 & 281 & 181 & 202 & 1231 \\
\hline
\end{tabular}


Table 2: Temporal variation in bird species composition at Tuti Island during the period of Octobermarch, 2011-2012.

\begin{tabular}{|c|c|c|c|c|c|c|c|}
\hline Common name & Scientific name & OCT. & NOV. & DEC. & FEB. & MAR. & TOTAL \\
\hline Little Egret & Egretta garzetta & 3 & 4 & 2 & 9 & 2 & 20 \\
\hline Cattle Egret & Bubulucus ibis & 5 & 9 & 5 & 27 & 3 & 49 \\
\hline Black kite & Milvus migrans & 11 & 2 & 4 & 0 & 3 & 20 \\
\hline Little Ringed Plover & Charadrius dubius & 6 & 4 & 1 & 2 & 0 & 13 \\
\hline Spur-winged Plover & Vanellus spinosus & 6 & 0 & 1 & 1 & 1 & 9 \\
\hline Green Sandpiper & Tringa ochropus & 3 & 4 & 0 & 0 & 0 & 7 \\
\hline Dunlin & Calidris alpine & 3 & 4 & 3 & 2 & 0 & 12 \\
\hline Mourning Collared Dove & Streptopelia decipiens & 11 & 8 & 10 & 3 & 3 & 35 \\
\hline Laughing Dove & Spilopelia senegalensis & 25 & 23 & 18 & 31 & 22 & 119 \\
\hline Namaqua Dove & Oena capensis & 3 & 0 & 0 & 0 & 0 & 3 \\
\hline Rose-ringed parakeet & Psittacula krameri & 7 & 4 & 4 & 3 & 4 & 22 \\
\hline Senegal Coucal & Centropus senegalensis & 3 & 4 & 1 & 2 & 2 & 12 \\
\hline Common swift & Apus apus & 5 & 4 & 0 & 0 & 0 & 9 \\
\hline Blue-naped Mousebird & Urocolius macrourus & 3 & 4 & 4 & 2 & 2 & 15 \\
\hline Pied Kingfisher & Ceryle rudis & 1 & 1 & 1 & 1 & 1 & 5 \\
\hline Eurasian Hoopoe & Upupa ерорs & 1 & 0 & 0 & 0 & 0 & 1 \\
\hline Little Bee-eater & Merops pusillus & 4 & 4 & 7 & 9 & 15 & 39 \\
\hline Crested Lark & Galerida cristata & 752 & 980 & 997 & 1010 & 990 & 4729 \\
\hline Barn Swallow & Hirundo rustica & 4 & 4 & 0 & 1 & 1 & 10 \\
\hline White-headed Babbler & Turdoides leucocephala & 9 & 7 & 2 & 0 & 0 & 18 \\
\hline White Wagtail & Motacilla alba & 2 & 2 & 3 & 2 & 1 & 10 \\
\hline Yellow Wagtail & Motacilla flava & 2 & 2 & 2 & 1 & 2 & 9 \\
\hline Black Scrub Robin & Cercotrichas podobe & 1 & 0 & 0 & 0 & 0 & 1 \\
\hline Common Bulbul & Pycnonotus barbatus & 7 & 5 & 2 & 2 & 1 & 17 \\
\hline Lesser Grey Shrike & Lanius minor & 2 & 3 & 3 & 2 & 1 & 11 \\
\hline House Sparrow & Passer domesticus & 75 & 130 & 98 & 137 & 99 & 539 \\
\hline Greater Blue-eared Starling & Lamprotornis chalybaeus & 15 & 0 & 0 & 0 & 0 & 15 \\
\hline African Silverbill & Lonchura cantans & 2 & 0 & 0 & 0 & 0 & 2 \\
\hline Red-billed Firefinch & Lagonosticta senegala & 2 & 2 & 2 & 1 & 2 & 9 \\
\hline Blue-billed Firefinch & Lagonosticta rubricata & 2 & 1 & 1 & 1 & 1 & 6 \\
\hline TOTAL & & 975 & 1215 & 1171 & 1249 & 1156 & 5766 \\
\hline
\end{tabular}

Table 3: Temporal variation in bird abundance at the study sites.

\begin{tabular}{|l|r|r|r|}
\hline Month & TA* at Sunut forest & TA* at Tuti Island & TOTAL \\
\hline Oct. & 284 & 975 & 1259 \\
\hline Nov. & 283 & 1215 & 1498 \\
\hline Dec. & 281 & 1171 & 1452 \\
\hline Feb. & 181 & 1249 & 1430 \\
\hline Mar. & 202 & 1156 & 1358 \\
\hline TOTAL & 1231 & 5766 & 6997 \\
\hline
\end{tabular}

* $\mathbf{T A}=$ Total abundance

\section{Spatial variations}

Variations in the bird composition between the two sites of the study were shown in Table (4).

\section{The avian diversity}

The avian diversity at each site was calculated according to Shannon diversity index (Table 5). The species richness ( $\mathrm{R}$ value) for Tuti was higher than that of Sunut forest (i.e. $30 \& 24$, respectively). The value of Shannon index $\left(H^{\prime}\right)$ was lower at Tuti than that at Sunut forest (i.e. $1.5 \& 2.33$, respectively). The species evenness (E value) was lower at Tuti than that at Sunut forest (i.e. $0.44 \& 0.73$, respectively). 
Table 4: Comparison of bird abundance between Sunut forest and Tuti Island.

\begin{tabular}{|c|c|c|c|c|c|c|c|c|c|}
\hline No. & Species & $\begin{array}{l}\text { TA at Tuti } \\
\text { Island }\end{array}$ & $\begin{array}{l}\text { TA at Sunut } \\
\text { Forest }\end{array}$ & Total & No. & Species & $\begin{array}{l}\text { TA at Tuti } \\
\text { Island }\end{array}$ & $\begin{array}{l}\text { TA at Sunut } \\
\text { forest }\end{array}$ & Total \\
\hline 1 & Grey Heron & 0 & 23 & 23 & 22 & Laughing Dove & 94 & 0 & 94 \\
\hline 2 & Black-headed Heron & 0 & 79 & 79 & 23 & Namaqua Dove & 1 & 0 & 1 \\
\hline 3 & Little Egret & 17 & 236 & 253 & 24 & Rose-ringed parakeet & 15 & 0 & 15 \\
\hline 4 & Cattle Egret & 44 & 168 & 212 & 25 & Senegal Coucal & 9 & 0 & 9 \\
\hline 5 & Greater Flamingo & 0 & 275 & 275 & 26 & Common swift & 4 & 0 & 4 \\
\hline 6 & Pink-backed Pelican & 0 & 23 & 23 & 27 & Blue-naped Mouse-bird & 12 & 0 & 12 \\
\hline 7 & White-faced Duck & 0 & 6 & 6 & 28 & Pied Kingfisher & 4 & 10 & 14 \\
\hline 8 & Garganey & 0 & 7 & 7 & 29 & Eurasian Hoopoe & 1 & 0 & 1 \\
\hline 9 & Black kite & 9 & 12 & 21 & 30 & Little Bee-eater & 35 & 0 & 35 \\
\hline 10 & Senegal Thick-knee & 0 & 18 & 18 & 31 & Crested Lark & 3977 & 78 & 4055 \\
\hline 11 & Little- ringed Plover & 3 & 38 & 41 & 32 & Barn Swallow & 6 & 0 & 6 \\
\hline 12 & Spur-winged Plover & 3 & 47 & 50 & 33 & White-headed Babbler & 9 & 0 & 9 \\
\hline 13 & Common Snipe & 0 & 6 & 6 & 34 & White Wagtail & 8 & 8 & 16 \\
\hline 14 & Black-winged Stilt & 0 & 10 & 10 & 35 & Yellow Wagtail & 7 & 20 & 27 \\
\hline 15 & Black-tailed Godwit & 0 & 27 & 27 & 36 & Black Scrub Robin & 1 & 0 & 1 \\
\hline 16 & Bar-tailed Godwit & 0 & 20 & 20 & 37 & Common Bulbul & 10 & 0 & 10 \\
\hline 17 & Green Sandpiper & 4 & 0 & 4 & 38 & Lesser Grey Shrike & 9 & 0 & 9 \\
\hline 18 & Dunlin & 9 & 16 & 25 & 39 & House Sparrow & 464 & 75 & 539 \\
\hline 19 & Green Shank & 0 & 13 & 13 & 40 & Greater Blue-eared Starling & 11 & 0 & 11 \\
\hline 20 & White-winged Tern & 0 & 16 & 16 & 41 & African Silverbill & 1 & 0 & 1 \\
\hline 21 & Mourning Collared Dove & 24 & 0 & 24 & & TOTAL & 4791 & 1216 & 6007 \\
\hline
\end{tabular}

$* \mathrm{TA}=$ Total abundance.

Table 5: Comparison of bird diversity between Sunut forest and Tuti Island.

\begin{tabular}{|c|c|c|c|c|c|c|c|}
\hline No. & Species & $\begin{array}{l}\text { RA at Tuti } \\
\text { island }\end{array}$ & $\begin{array}{l}\text { RA at Sunut } \\
\text { forest }\end{array}$ & No. & Species & $\begin{array}{l}\text { RA at Tuti } \\
\text { island }\end{array}$ & $\begin{array}{l}\text { RA at Sunut } \\
\text { forest }\end{array}$ \\
\hline 1 & Grey Heron & --- & 0.01 & 22 & Laughing Dove & 0.02 & -- \\
\hline 2 & Black-headed Heron & --- & 0.07 & 23 & Namaqua Dove & 0.001 & --- \\
\hline 3 & Little Egret & 0.003 & 0.19 & 24 & Rose-ringed parakeet & 0.004 & ---- \\
\hline 4 & Cattle Egret & 0.008 & 0.14 & 25 & Senegal Coucal & 0.002 & --- \\
\hline 5 & Greater Flamingo & --- & 0.23 & 26 & Common swift & 0.002 & --- \\
\hline 6 & Pink-backed Pelican & --- & 0.02 & 27 & Blue-naped Mousebird & 0.003 & --- \\
\hline 7 & White-faced Duck & --- & 0.01 & 28 & Pied Kingfisher & 0.001 & 0.01 \\
\hline 8 & Garganey & --- & 0.01 & 29 & Eurasian Hoopoe & 0.0007 & --- \\
\hline 9 & Black kite & 0.003 & 0.01 & 30 & Little Bee-eater & 0.007 & --- \\
\hline 10 & Senegal Thick-knee & --- & 0.01 & 31 & Crested Lark & 0.82 & 0.06 \\
\hline 11 & Little-ringed Plover & 0.002 & 0.03 & 32 & Barn Swallow & 0.002 & --- \\
\hline 12 & Spur-winged Plover & 0.002 & 0.04 & 33 & White-headed Babbler & 0.003 & --- \\
\hline 13 & Common Snipe & --- & 0.01 & 34 & White Wagtail & 0.002 & 0.01 \\
\hline 14 & Black-winged Stilt & --- & 0.01 & 35 & Yellow Wagtail & 0.002 & 0.02 \\
\hline 15 & Black-tailed Godwit & --- & 0.02 & 36 & Black Scrub Robin & 0.0007 & --- \\
\hline 16 & Bar-tailed Godwit & --- & 0.02 & 37 & Common Bulbul & 0.003 & --- \\
\hline 17 & Green Sandpiper & 0.001 & ----- & 38 & Lesser Grey Shrike & 0.002 & --- \\
\hline 18 & Dunlin & 0.002 & 0.01 & 39 & House Sparrow & 0.09 & 0.067 \\
\hline 19 & Green Shank & --- & 0.01 & 40 & $\begin{array}{l}\text { Greater } \quad \text { Blue-eared } \\
\text { Starling }\end{array}$ & 0.003 & 0 \\
\hline 20 & White-winged Tern & --- & 0.01 & 41 & African Silverbill & 0.0003 & 0 \\
\hline 21 & $\begin{array}{l}\text { Mourning Collared } \\
\text { Dove }\end{array}$ & 0.006 & --- & & & & \\
\hline
\end{tabular}

* RA= Relative abundance.

\section{DISCUSSION}

At Sunut forest and Tuti Island, both the density and species composition of birds were found to vary with months. The temporal variation in bird community structure could be attributed to two different factors: first, bird migrational patterns; during the period of observation, some migrating birds (local and palaearctic migrants) arrive at the study sites, using them as breeding grounds or as stopover sites for food supply. The seasonal movements of migrational birds to and from the study sites are likely to exert deep influence on the avifauna composition. The second factor that underlies the temporal variation is the cyclic changes in plant cover and insect density that are induced by the seasonal cycle of water availability. These changes 
affect food availability and thus the attractiveness of the sites for the different species of birds.

In this study, the abundance and diversity of bird species has been compared between two sites at Khartoum that are, Tuti Island and Sunut forest. The two sites are characterized by extremely similar climate, since they are separated only by few kilometers. Moreover, the plant cover and the seasonal variation at both sites are deeply influenced by the annual flooding of the Nile River, since they are partially submerged during the autumn months. Unlike the surrounding arid region, water is available throughout the year, due to the proximity to the Nile. In addition, The Nile flooding supplies both sites with immense amounts of nutrient-reach sediments. As a consequence, the habitat quality and the plant cover at both sites are considerably richer than that at the surrounding, semi-desert region of Khartoum. However, the two sites differ with respect to one critical factor that is, the intensity of human impact; the habitat at Tuti is shaped by agricultural activities; the island contains a small village that is surrounded by agricultural fields where vegetables and fruits are grown. On the other side, Sunut forest remains a wild habitat to a large extent; the plant cover at the site is dominated by Acacia nilotica trees and agricultural activities are limited to the narrow band extending along the White Nile River bank.

Because vegetation cover is known to have a strong influence on the avifauna (Scott Mills et al., 1989), it is expected that the bird diversity at the two sites will vary following the habitat difference. Overall, the findings of the present study support this prediction. The numbers of bird species observed at the two sites showed considerable difference, with Tuti Island representing higher species richness; 30 species of birds have been reported at Tuti compared to 24 species at Sunut forest. The total abundance of individual birds at Tuti Island was substantially higher than that at Sunut forest. In addition to the numbers of species and individuals, the species composition at the two sites showed considerable variation; each of the two sites was found to host bird species not found in the other site (e.g. Parakeet at Tuti and Duck at Sunut). Moreover, the highly abundant species also differs between the two sites, with the Crested Lark being the most abundant in Tuti while the Greater Flamingo was the most abundant in Sunut. Interestingly, although both species richness and abundance were relatively higher at Tuti, the value of Shannon diversity index was higher at Sunut. The reason is that the relative abundance of bird species is more even at Sunut, while at Tuti few species represent most of the community.

Despite the apparent similarity between Tuti Island and Sunut forest and their proximity to each other, the marked variation in bird community structure suggest the existence of considerable habitat variability that affects bird communities at the two sites. The most important habitat difference regards the floral structure; in Sunut forest, one tree species, Acacia nilotica, dominates the plant cover, while in Tuti Island the flora is much more diverse and complex, containing variable trees, shrubs, grasses and herbs. This difference implies that Tuti have a wider range of microhabitats for different species of birds and hence the higher species richness at Tuti. Another important habitat difference is that the extensive agricultural activity at Tuti Island leads to higher food availability for resident and migrating birds. Due to agriculture, Tuti is more attractive for both seed-eating and insect-eating birds. In Sunut forest, agriculture is limited to the narrow external zone that borders the White Nile. Most of the forest area lacks any vegetation cover except A. nilotica trees. Moreover, the buildings at Tuti Island provide shelter and nesting grounds for many species of birds that are not available at Sunut forest. On the other side, aquatic birds 
such as ducks may be especially attracted to Sunut forest because of the presence of water pools within the inner part of the forest that are isolated from human activities.

Overall, it appears that the avian community at Tuti Island is characterized by higher abundance of birds, higher species richness, but less species evenness than that at Sunut forest. Urban sites are theoretically expected to show lower richness than respective wild sites (see introduction). The reason why this rule does not apply to the case of the urban Tuti Island and the wild Sunut forest is that the former has much more heterogeneous and diverse plant cover than the later, thus attracting birds with variable feeding habits and life styles. The availability of food sources at Tuti Island causes the higher bird abundance but it also leads to the lower species evenness at the site; agriculture favors particular species of birds (e.g. insectivorous, granivorous species) thus driving these species toward large population sizes and reducing the overall species equality/evenness at Tuti Island.

The diversity at Tuti Island and Sunut forest is threatened by the increasing urbanizational development taking place at Khartoum, especially the pressure posed by the construction activities (e.g. the Sunut construction project and Tuti Bridge) (Eltayeb et al. 2012). Thus, it is important to establish a database on the biological diversity at the two sites so as to guide future management plans and conservation activities taking place there. We recommend future research to adopt larger scale of observation, both spatially and temporally. Moreover, the diversity of other key group such as plants and arthropods should be investigated as well in order to provide an integrated view for the ecological status at the two sites. Biodiversity surveys should cover the surrounding semi-desert area so as to distinguish the biodiversity patterns that are specific to each site from those characterizing the entire Khartoum region.

\section{REFERENCES}

Abd-Alrahman, S.A. (1998). Birds of Sunut Forest. M. Sc. Thesis. Zoology Department, Faculty of Science, University of Khartoum.

Ahmed, H.M. (1998). The auto ecology of Acacia nilotica: case study Khartoum Sunut Forest. M. Sc. Thesis. Botany Department, Faculty of Science, University of Khartoum.

Altayeb, A.M. and Hamed, D.M. (2003). Information Sheet on the Ramsar Wetlands (RIS).

Askins, R.A., Lynch, J.F. and Greenburg, R. (1990). Population declines in migratory birds in eastern North America. Current Ornithology, 7: 1-57.

Bock, C.E., Bock, J.H. and Bennett, B.C. (2001). Songbird abundance in grasslands at a suburban interface on the Colorado high plains. Studies in Avian biology, 19: 131-136.

Cloudsley-Thompson, J.L. (1964). Guide to desert invertebrates of Khartoum Province. Sudan Notes and Records, 45: 127-136.

Elobeid, M.A. (1990). The invertebrate fauna of four selected islands in Khartoum Province. B. Sc. Hons. Dissertation, Zoology Department, Faculty of Science, University of Khartoum.

Eltayeb, H., Idris, E., Adam, A. Ezaldeen, T. and Hamed, D. (2012). A forest in a city: Biodiversity at Sunut forest, Khartoum, Sudan. The Egyptian Academic Journal of Biological Sciences - Zoology, 4: 199-209.

Emlen, J.T. (1974). An urban bird community in Tucson, Arizona: derivation, structure, regulation. Condor, 76: 184-197. 
Lado, B.D. (1994). Birds of Sunut forest in Khartoum. M. Sc. Thesis. Zoology Department, Faculty of Science, University of Khartoum.

Marzluff, J.M. (1997). Effects of urbanization and recreation on songbirds. In: Block, W.M., Finch, D.M. (Eds.). Songbird Ecology in southwestern Ponderosa Pine Forests: A literature Review. Technical report.

Mohamed, A.O. (1986). An ecological study on the regeneration of Acacia nilotica in the Sunut Forest, Khartoum. B. Sc. Hons. Dissertation, Botany Department, Faculty of Science, University of Khartoum.

Nikolaus, G. (1987). Distribution atlas of Sudan birds with notes on habitat and status. Bonner zoologische monographien, Bonn.

Salah Eldin, H. (1997). Cutaneous leishmaniasis in Tuti Island. Khartoum, Sudan: Across sectional study of school children and a sample of the population. M. Sc. Thesis, University of Khartoum.

Scott Mills, G., Dunning J.B., and Bates, J.M. (1989). Effects of urbanization on breeding bird community structure in southwestern desert habitats. Condor, 91: 416-428.

Shawki and Musnad (1964). Guide to Khartoum Arboretum and forest nursery. Forest Department Bulletin, 9: 16-22.

Sinclair, I. and Ryan, P. (2003). Birds of Africa south of the Sahara: A comprehensive illustrated field guide. Struik publishers, Cape Town. 


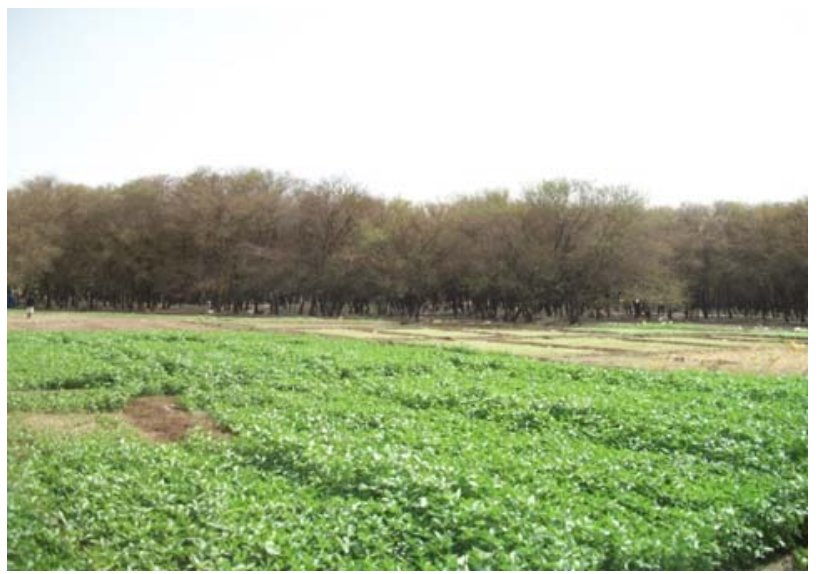

Fig. 1(a): Sunut forest.

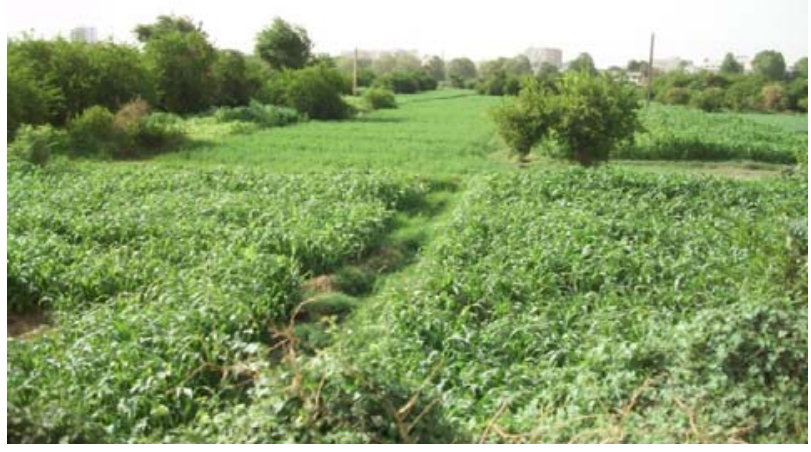

Fig. 2(a): Tuti Island.

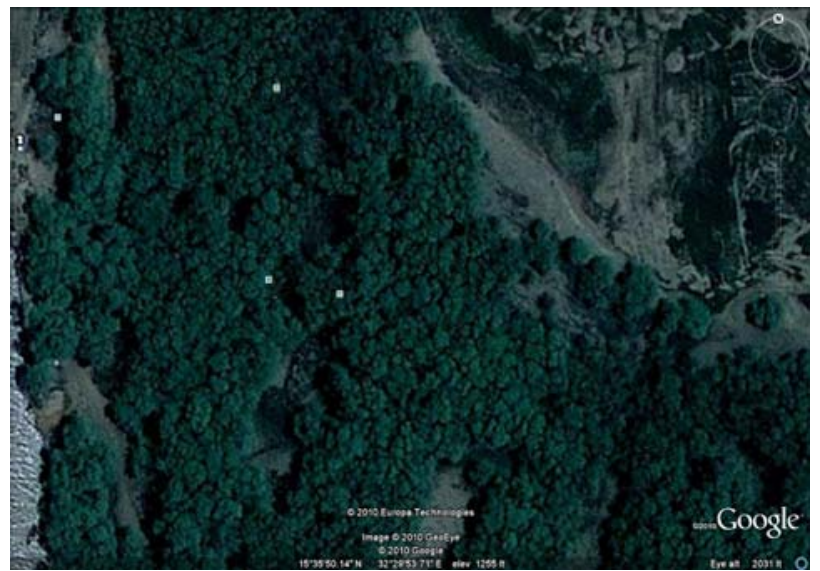

Fig. 1(b): Sunut forest (satellite image).

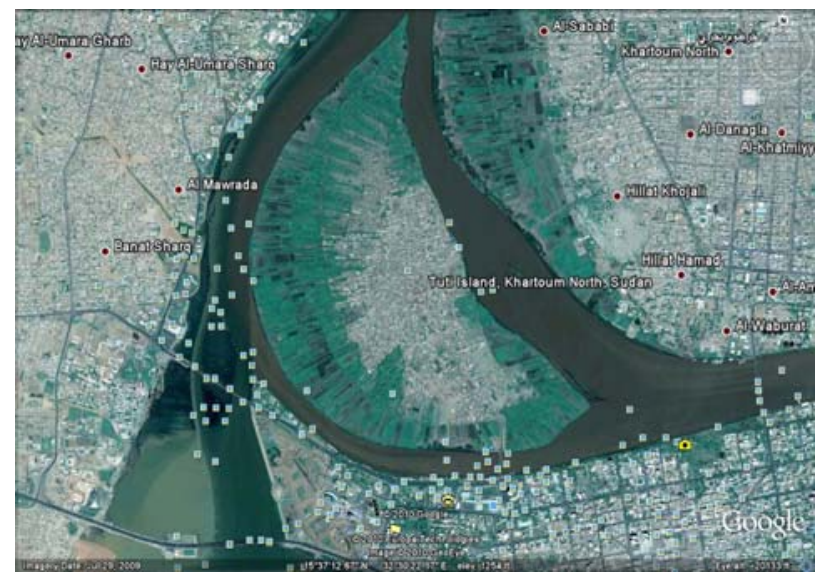

Fig. 2(b): Tuti Island (Satellite image). 


\section{ARABIC SUMMARY}

\section{تنوع الطيور في موقعين بالخرطوم- السودان \\ عثمان صلاح* و ايهاب ادريس*}

*قسم علم الحيوان- كلية العلوم- جامعة الخرطوم- ص. ب. 321 الرمز البريدي 11115 الخرطومالسودان

إن التنوع الحيوي للطيور يتأثر بقوه بطبيعة الموطن و لهذا فمن المتوقع أن تتباين أنواع و أعداد الطيور

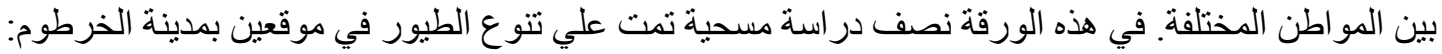

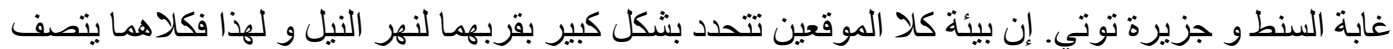

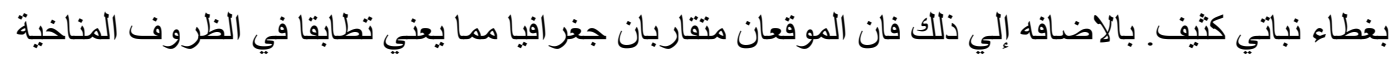

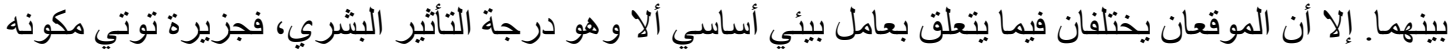

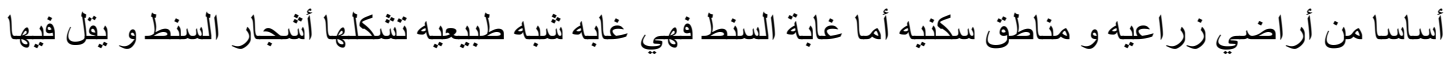

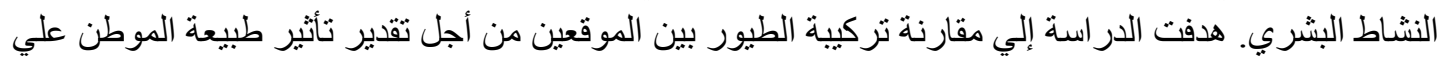

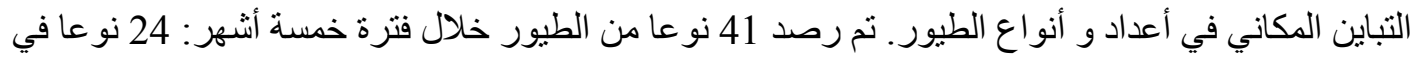

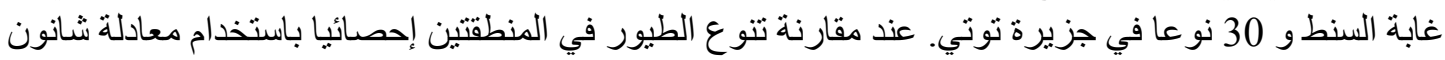

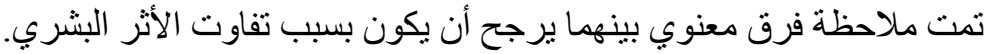

